\title{
Evaluation of DSSAT-CANEGRO model for phenology and yield attributes of sugarcane grown in different agroclimatic zones of Punjab, India
}

\author{
JASHANDEEP SINGH ${ }^{1}$, S.K. MISHRA ${ }^{1 *}$, P.K. KINGRA ${ }^{3}$, KULDEEP SINGH $^{1}$, BARUN BISWAS $^{2}$, \\ and VIKRANT SINGH ${ }^{1}$ \\ ${ }^{1}$ Regional Research Station, Faridkot, ${ }^{2}$ Regional Research Station, Gurdaspur \\ ${ }^{3}$ Department of Climate Change and Agricultural Meteorology, Punjab Agricultural University, Ludhiana \\ *Corresponding author: sudhirmet@pau.edu
}

\begin{abstract}
DSSAT-CANEGRO model was calibrated and validated for four sugarcane cultivars planted at three dates in two agroclimatic zones of Indian Punjab. For calibration two years (2015-16 and 2016-17) data on phenological stages, growth and yield attributes of sugarcane were recorded from the field experiments conducted under All India Coordinated Research Project (AICRP) on sugarcane at Faridkot whereas, for validation field experiments were conducted during 2017-18 at Regional Research Station (RRS) of Punjab. Faridkot representing western plain zone and Gurdaspur representing undulating plain zone. The genetic coefficients were derived separately for each cultivar. The results revealed that at Faridkot and Gurdaspur, the observed fresh cane yield was 89.8 and $98.6\left(\mathrm{t} \mathrm{ha}^{-1}\right)$, whereas simulated was 90.3 and $105.6 \mathrm{t} \mathrm{ha}^{-1}$ respectively. The mean observed days to reach physiological maturity were $297.9 \pm 14.2$ at Faridkot and $298 \pm 16.5$ days at Gurdaspur. Whereas, CANEGRO model simulated $305.4 \pm 17.1$ and $304.3 \pm 17.4$ days, respectively. The mean percent error for simulation of aerial dry biomass was 7.02 per cent at Faridkot and 11.5 per cent at Gurdaspur. For different phenological stages, growth as well as yield attributes, the maximum RMSE remained below 8.65 which confirmed the strength of the model. Different statistical procedures adopted for validation of the model proved the efficiency of the DSSAT-CANEGRO model for simulation of the crop growth and production with fair degree of accuracy.
\end{abstract}

Key words: Sugarcane, calibration, validation, CANEGRO-DSSAT model (v 4.6), Faridkot, Gurdaspur.

Sugarcane (Saccharum spp. L.) is one of the important sugar producing cash crops of India and world. It plays a significant role in the Indian agricultural and industrial economy.India ranks second in sugarcane area (5.0 million hectares) and production (340 million tonnes) after Brazil but in terms of productivity, it holds tenth rank. In India, sugar industry is second largest agriculture based processing industry after textiles. During 2015-16, sugarcane was grown on 4.93 million hectare area with total production of 348.4 million tonnes in India. At present, approximately 6 million Indian farmers are involved in sugarcane cultivation (Mall et al.,2016).Among the sugarcane producing states of India, Punjab holds tenth rank in sugarcane production (6.76 million tonnes) from 92 thousands hectares area under this crop. In Punjab, sugarcane are mainly grown over 15 districts but, Hoshiarpur, Gurdaspur and Jalandhar are high producing districts that jointly share about 57.36 percent of total sugarcane production of the state. Fazilka district holds highest productivity $\left(89.24 \mathrm{t} \mathrm{ha}^{-1}\right)$ whereas; Hoshiarpur district holds largest area ( 22 thousand hectares) under this crop.The sugarcane productivity of Punjab (60.15 t $\left.\mathrm{ha}^{-1}\right)$ is less than the average sugarcane productivity of the country $\left(65.55 \mathrm{tha}^{-1}\right)$. Though, agroclimatic conditions of Punjab have potential to increase the sugarcane production, but the spatio-temporal variability in the weather parameters often lead to the declined cane and sugar yields in different zones of the state(Anon., 2017).

Crop growth simulation models are useful tool to evaluate the effects of weather (maximum temperature, minimum temperature, solar radiation, rainfall, etc.), crop physiological properties (genotype characteristics variety constant, etc.), soil factors (physical properties, available water depth, etc.) and crop management data (planting date, amount and timing of irrigation, fertilizer applications, etc.) and other factors like pests and diseases on growth, development and yield of crops. CANEGRO is one of the 16 crop models integrated within DSSAT software (Jones et al., 2003). It is a prominent sugarcane crop growth simulation model that has been widely used in various studies of 
Table 1: Physio-chemical characteristics of soil at Faridkot and Gurdaspur

\begin{tabular}{|c|c|c|c|c|c|c|c|c|c|}
\hline Depth $(\mathrm{cm})$ & $\mathrm{pH}$ & $\mathrm{EC}$ & $\mathrm{OC}$ & $\mathrm{P}\left(\mathrm{kgha}^{-1}\right)$ & $\mathrm{K}\left(\mathrm{kgha}^{-1}\right)$ & Sand $(\%)$ & Silt $(\%)$ & Clay $(\%)$ & Texture \\
\hline \multicolumn{10}{|c|}{ Faridkot: Agroclimatic zone IV } \\
\hline 0-15 & 8.67 & 0.57 & 0.442 & 15.62 & 272.5 & 76 & 13 & 11 & Sandy loam \\
\hline $15-30$ & 8.57 & 0.59 & 0.247 & 14.37 & 239.5 & 65.8 & 12 & 20.2 & Sandy loam \\
\hline \multicolumn{10}{|c|}{ Gurdaspur: Agroclimatic zone II } \\
\hline $0-15$ & 8.4 & 0.51 & 0.64 & 26.25 & 312.5 & 29.5 & 51.3 & 20.2 & Silt loam \\
\hline $15-30$ & 8.3 & 0.53 & 0.51 & 20.5 & 257.5 & 27.3 & 53.5 & 20.2 & Silt loam \\
\hline
\end{tabular}

research and management (Inman-Bamber et al, 1998; Singels and Bezuidenhout., 2002). CANEGRO model integrates the influences of various factors on productivity of sugarcane crop. The Punjab state experiences significant weather variation from year to year, often leading to the declined cane and sugar yields in different zones of the state. In view of this, DSSAT-CANEGRO model ( $v 4.6)$ has been evaluated to simulate phenology and yield attributes of sugarcane in different agroclimatic zones of Indian Punjab, which can prove useful in decision making to improve productivity of sugarcane.

\section{MATERIALS AND METHOD}

The field experiments were carried out at Punjab Agricultural University, Regional Research Stations Faridkot (Lat. 30 40' N, Long. 74 $44^{\prime}$ E and altitude $200 \mathrm{~m}$ amsl) and Gurdaspur (Lat. 32 $40^{\prime}$ N, Long. $75^{\circ} 40^{\prime}$ E and altitude 241 $\mathrm{m}$ amsl) comprising four varieties ( $\mathrm{CoPb} 91, \mathrm{CoJ} 88, \mathrm{Co} 118$ and Co238) of sugarcane planted on three planting dates (25 $5^{\text {th }}$ February, $25^{\text {th }}$ March and $25^{\text {th }}$ April) at both the locations during 2017-18. In addition, previous two years (2015-16 and 2016-17) data on growth and yield attributes were collected from field experiments carried out under AICRP on sugarcane at PAU RRS, Faridkot. Thus, total four environments were created for the present investigation. The soil was sandy loam at Faridkot and silt loam at Gurdaspur (Table 1). The daily weather data were collected from respective agrometeorological observatory.

\section{Calibration and validation of the model}

Model calibration is adjustment of model parameters or coefficient in a functional relationship so that the model behavior matches with observed data. The two years (201516 and 2016-17) data generated at PAU Regional Research Station, Faridkot was used for model calibration. Model validation is a simplest comparison between the model simulated and observed values obtained from actual or field experiment. If the simulated values lie within the predicted confluence, the model is considered as valid. Thus, validation is used as estimation of the model for its efficacy. For validation of model field experimental data collected during 2017-18 at Faridkot and Gurdaspur was used. Different statistical procedures viz., mean, standard deviation, mean absolute error (MAE), mean bias error (MBE), root mean square error (RMSE), etc. were used to evaluate the performance of model following Mishra et al. (2015).

\section{RESULTS AND DISCUSSION}

\section{Calibration and validation of CANEGRO model}

Calibration of DSSAT- CANEGRO model ( $v 4.6)$ was done by running the model repeatedly until simulated phenology, growth and yield parameters reached very close to the observed values following Singh et al., (2010) and Mishra et al., (2017). The calibrated genetic coefficients used for validation are presented in Table 2. Simulations using independent data set for validation were carried out for estimated sucrose dry mass $\left(\mathrm{t} \mathrm{ha}^{-1}\right)$, aerial dry biomass $(\mathrm{t}$ $\left.\mathrm{ha}^{-1}\right)$, leaf area index and fresh cane yield $\left(\mathrm{t} \mathrm{ha}^{-1}\right)$. The observed and simulated data on phenological stages, growth and yield attributes are compared using statistical parameters viz. RMSE, MBE, and d-Stat (Fig. $1 \& 2$ ).

\section{Phenological stages}

The observed and simulated phenological stages viz. emergence, peak tiller stage and maturity are presented in Fig. 1. The observed days taken to emergence were 54.0 \pm 4.0 at Faridkot and 53.8 \pm 5.9 at Gurdaspur while, simulated emergence days were $51.9 \pm 3.9$ and $52.6 \pm 4$.2, for respective locations. The index of agreement was 0.9 days for Faridkot and 0.8 for Gurdaspur and with RMSE of 2.29 for Faridkot and 4.07for Gurdaspur.The 1:1 line (Fig. 1a) clearly shows the close association between observed and simulated days of emergence.

The observed days taken for mean peak tiller population were $129.8 \pm 6.7$ days at Faridkot and at Gurdaspur 
Table 2: Derived genetic coefficient of CANEGRO model for sugarcane cultivars

\begin{tabular}{|c|c|c|c|c|c|}
\hline Description & Units & $\mathrm{CoPb} 91$ & $\mathrm{CoJ} 88$ & Co 118 & Co 238 \\
\hline $\begin{array}{l}\text { PARCEmax = Maximum (no stress) radiation conversion } \\
\text { efficiency expressed as assimilate produced before } \\
\text { respiration, per unit PAR }\end{array}$ & $(\mathrm{g} / \mathrm{MJ})$ & 9.9 & 9.9 & 9.92 & 9.92 \\
\hline $\begin{array}{l}\text { APFMX = Maximum fraction of dry mass increments } \\
\text { that can be allocated to aerial dry mass }\end{array}$ & $(\mathrm{t} / \mathrm{t})$ & 0.9 & 0.88 & 0.88 & 0.89 \\
\hline $\begin{array}{l}\text { STKPFMAX = Fraction of daily aerial dry mass } \\
\text { increments partitioned to stalk at high temperatures in } \\
\text { a mature crop }\end{array}$ & $(\mathrm{t} / \mathrm{t})$ & 0.66 & 0.65 & 0.68 & 0.66 \\
\hline $\begin{array}{l}\text { SUCA = Sucrose partitioning parameter: Maximum } \\
\text { sucrose contents in the base of stalk }\end{array}$ & $(\mathrm{t} / \mathrm{t})$ & 0.58 & 0.58 & 0.58 & 0.62 \\
\hline $\begin{array}{l}\text { TBFT }=\text { Sucrose partitioning: Temperature at which } \\
\text { partitioning of unstressed stalk mass increments to } \\
\text { sucrose is } 50 \% \text { of the maximum value }\end{array}$ & $\left({ }^{\circ} \mathrm{C}\right)$ & 27 & 25 & 28 & 27 \\
\hline Tthalfo $=$ Thermal time to half canopy & $\left({ }^{\circ} \mathrm{C}\right.$ days $)$ & 260 & 250 & 250 & 250 \\
\hline Tbase $=$ Base temperature for canopy development & ( ${ }^{\circ} \mathrm{C}$ days) & 16 & 16 & 16 & 16 \\
\hline $\begin{array}{l}\text { LFMAX = Maximum number of green leaves a healthy, } \\
\text { adequately-watered plant will have after it is old } \\
\text { enough to lose some leaves }\end{array}$ & 12 & 12 & 12 & 12 & \\
\hline $\begin{array}{l}\text { MXLFAREA = Maximum leaf area assigned to all leaves } \\
\text { above leaf number MXLFARNO }\end{array}$ & $\left(\mathrm{cm}^{2)}\right.$ & 360 & 350 & 355 & 360 \\
\hline $\begin{array}{l}\text { MXFARNO = Leaf number above which leaf area is } \\
\text { limited to MXLFAREA }\end{array}$ & 15 & 15 & 15 & 16 & \\
\hline $\begin{array}{l}\text { PI } 1 \text { = Phyllocron interval } 1 \text { (for leaf numbers below } \\
\text { Pswitch }\end{array}$ & $\begin{array}{l}\left({ }^{\circ} \mathrm{C} \text { days, base }\right. \\
\text { TTBASELFEX) }\end{array}$ & 70 & 70 & 90 & 90 \\
\hline PI2 = Phyllocron interval 2 (for leaf numbers above & $\left({ }^{\circ} \mathrm{C}\right.$ days, base & & & & \\
\hline Pswitch & TTBASELFEX) & 170 & 170 & 170 & 170 \\
\hline $\begin{array}{l}\text { PSWITCH = Leaf number at which the phyllocron } \\
\text { changes. }\end{array}$ & (Number) & 18 & 17 & 16 & 14 \\
\hline TTPLNTEM $=$ Thermal time to emergence for a plant crop & $\begin{array}{l}\left({ }^{\circ} \mathrm{C} \text { days, base }\right. \\
\text { TTBASEEM })\end{array}$ & 438 & 440 & 440 & 435 \\
\hline $\begin{array}{l}\text { CHUPIBASE }=\text { Thermal time }(\text { base TTBASEEM) from } \\
\text { emergence to start of stalk growth }\end{array}$ & 1050 & 1000 & 1050 & 1000 & \\
\hline $\begin{array}{l}\text { TT_POPGROWTH }=\text { Thermal time to peak tiller } \\
\text { population }\end{array}$ & $\begin{array}{l}\left({ }^{\circ} \mathrm{C} \text { days, }\right. \\
\text { TTBASEPOP })\end{array}$ & 700 & 680 & 750 & 740 \\
\hline MAX_POP $=$ Maximum tiller population & $\left(\mathrm{stalks} / \mathrm{m}^{2}\right)$ & 28 & 27 & 28 & 28 \\
\hline POPTT $16=$ Stalk population at $/$ after $1600^{\circ}$ days & $\left(\mathrm{m}^{2}\right)$ & 13 & 13 & 12 & 11 \\
\hline
\end{tabular}

$130.4 \pm 8.2$ days while, simulated were $126.6 \pm 6.8$ days at Faridkot and $126.6 \pm 7.0$ days at Gurdaspur (Fig. 1b). There was close association between simulated and observed days taken to reach at peak tillers population stage of sugarcane as evident from higher d-stat values and low RMSE values.
The mean observed days to physiological maturity were $298.0 \pm 14.0$ at Faridkot and $298 \pm 16.5$ days at Gurdaspur (Fig. 1c) and the simulated days to physiological maturity were $305.0 \pm 17.0$ and $304.3 \pm 16.5$ days, respectively. The simulated values were slightly higher than the observed ones. The higher values of d-Stat (0.91 and 0.95) and lower 

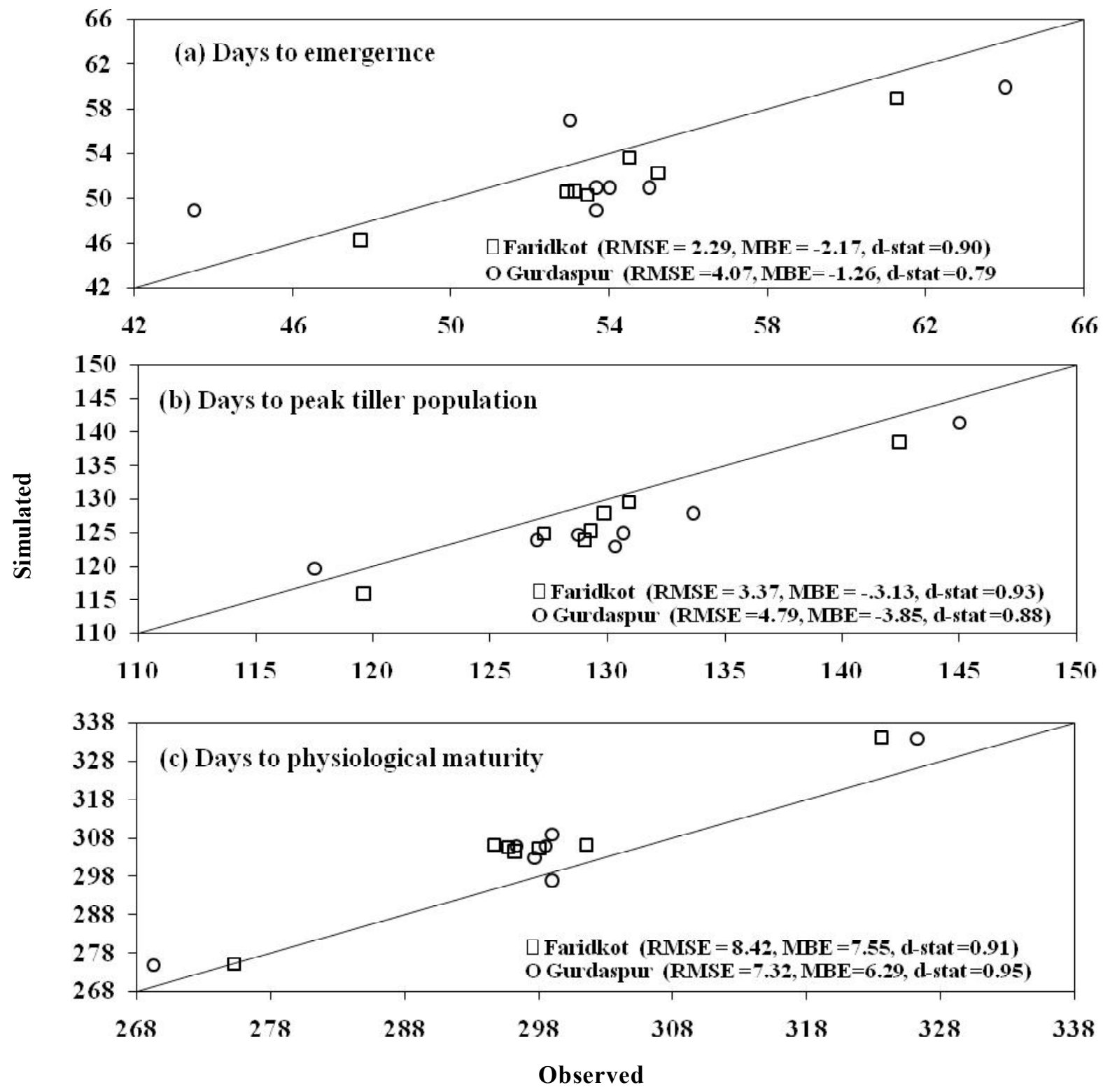

Fig 1: Observed and simulated phenological stages of sugarcane

RMSE (8.42 and 7.32days) depicted the minimum difference between observed and simulated days to physiological maturity.

\section{Growth and yield attributes}

The leaf area index (LAI) of sugarcane were 3.8 and 3.9 at Faridkot and Gurdaspur respectively whereas, the simulated LAI were 3.9 to 4.2 . The high d-stat $(0.92 \& 0.97)$ and low RMSE $(0.19 \& 0.34)$ indicate the usefulness of the model (Fig.2a). Carvalho et al., (2018) also tested CANEGRO model for LAI and found similar results.

The observed fresh cane yield were 89.9 and $98.6(\mathrm{t}$ $\left.\mathrm{ha}^{-1}\right)$ at Faridkot and Gurdaspur, whereas the simulated yield were 90.3 and 105.7 tha $^{-1}$ at respective stations (Fig. 2b). The
RMSE and d-stat values were 4.67 and 0.98 at Faridkot and 8.65 and 0.94 , respectively at Gurdaspur. Mishra et al.,(2017) also observed high correlation coefficient $(\mathrm{r}=0.91)$ between observed and simulated fresh cane yield. Singh et al., (2010) also validated CANEGRO model with high coefficient of determination $\left(\mathrm{R}^{2}=0.77\right)$ for fresh stalk yield of sugarcane.

The mean observed sucrose dry mass was $5.70 \pm 1.2$ $\mathrm{t} \mathrm{ha}^{-1}$ at Faridkot and $6.31 \pm 1.3$ tha $^{-1}$ at Gurdaspur whereas, simulated sucrose drymass by CANEGRO model was $6.0 \pm 1.2$ and $6.95 \pm 1.4 \mathrm{t} \mathrm{ha}^{-1}$ at respective stations (Fig. 2c). The statistical parameters such as RMSE were 0.44 and 0.82 t ha $^{-1}$, MBE were 0.29 and 0.64 and d-stat were 0.96 and 0.89 at Faridkot and Gurdaspur respectively. Bhengra et al., (2016) also obtained good coefficient of determination 


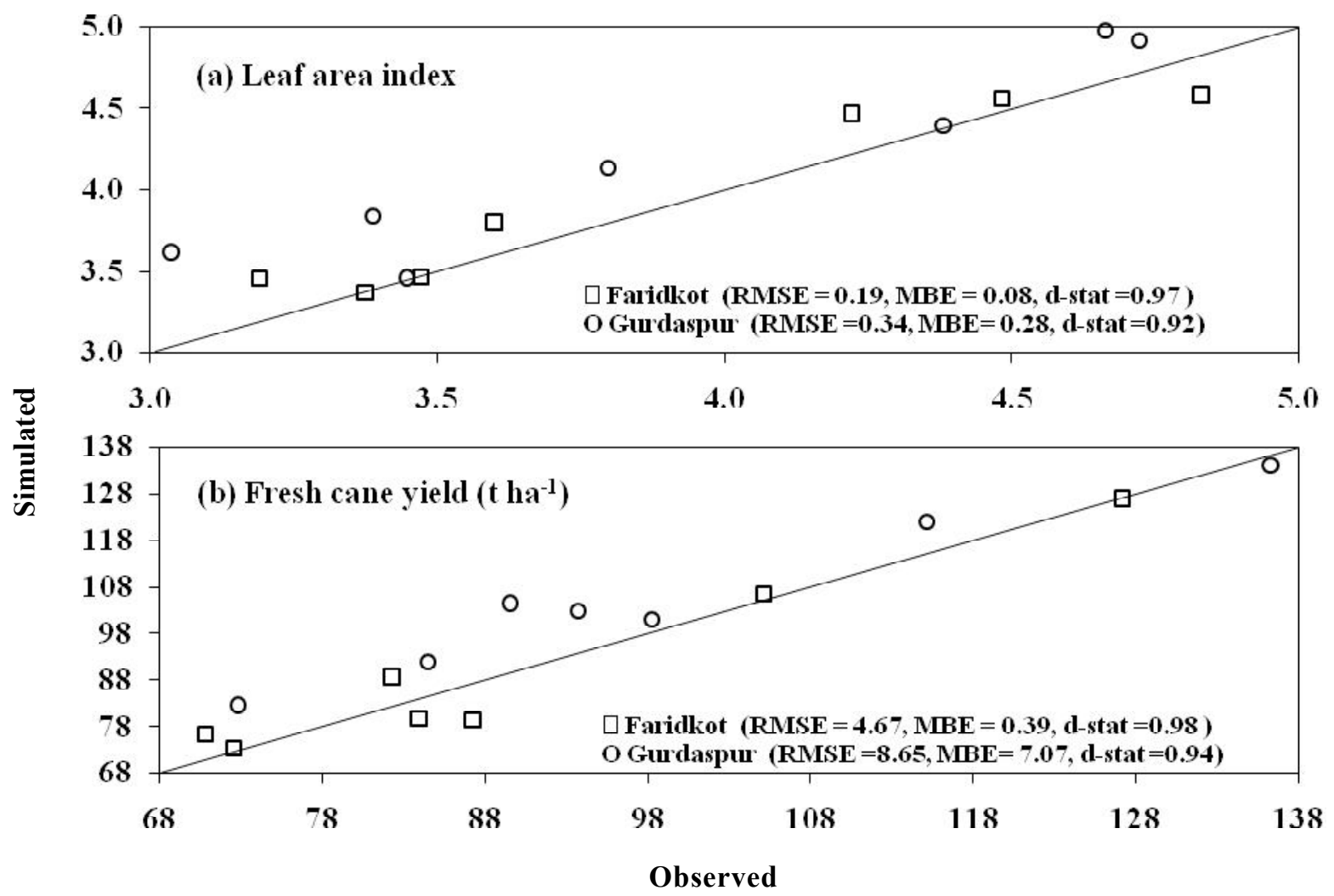

Fig 2: Observed and simulated yield and yield attributes of sugarcane

$\left(\mathrm{R}^{2}=0.57\right)$ between measured and simulated sucrose quantity with 11.75 per cent nRMSE and $0.85 \mathrm{D}$ index.

The aerial biomass recorded was $40.5 \mathrm{t} \mathrm{ha}^{-1}$ at Gurdaspur and $35.5 \mathrm{t} \mathrm{ha}^{-1}$ at Faridkot while thesimulated values were $45.1 \mathrm{t} \mathrm{ha}^{-1}$ and $38.1 \mathrm{tha}^{-1}$ at respective stations (Fig. 2d). The model simulated aerial drybiomass with RMSE of 4.08 and 5.64 tha ${ }^{-1}, \mathrm{MBE}$ of 2.50 and 4.67, d-Stat of 0.89 and 0.89 at Faridkot and Gurdaspur respectively. Carvalho et al., (2018) simulated above ground biomass by CANEGRO model with -19.2 per cent estimation errors. CANEGRO model could satisfactorily explained $70-83$ per cent of the observed cane yield (biomass) variation (Inman-Bamber et al., 1998).

\section{CONCLUSION}

The DSSAT-CANEGRO model satisfactorily simulated phenology and yield attributes (leaf area index, fresh cane yield, sucrose dry mass and aerial dry mass) of sugarcane cultivars (CoPb 91, CoJ 88, Co 118 and Co 238) for the both agroclimatic zones of the Punjab as evident by low RMSE and high d-stat values. Thus, the calibrated model can be used effectively for decision making like selection of the tillage method, sowing/planting windows, input (irrigation, fertilizer, chemical) application, harvesting, export/import of the produce, etc.

\section{ACKNOWLDEGEMENT}

Authors are extremely grateful to the Director (PAU, RRS, Faridkot and PAU, RRS, Gurdaspur) for providing the required facilities and supports to complete the present investigation.

\section{REFERENCES}

Anonymous., (2017). www.indianstat.com (2016-17).

Bhengra, A.H., Yadav, M.K., Patel, C., Singh, P.K., Singh, K.K. and Singh, R.S. (2016). Calibration and validation study of sugarcane (DSSAT-CANEGRO v4.6.1) model over North Indian region. J. Agrometeorol., 18:234-239.

Carvalho,A. L. D., Souza, J. L. D., Almeida,A. C. D. S., Lyra, G. B, Teodoro, I., Junior, R. A. F. J., Magalhaes, I. D. and Santos, L. R. (2018). Sugarcane productivity simulation under different planting times by DSSAT/CANEGRO model inAlagoas, Brazil.Emi. J. Food Agri., 30(3):190198.

Inman-Bamber, N.G., Singels A. and Muchow, R.C. (1998)A systems approach to benchmarking for sugarcane production in Australia and South Africa.Proc. S. Afri. Sugar Tech. Assoc., 72: 3-9. 
Jones, J.W., Hoogenboom, G., Porkr, C.H., Boote, K.J., Batchalor, W.D., Hunt, L.A., Widkens, P.W., Singh, U., Gijsman, A.J. and Ritchie, J.T. (2003). The DSSAT Cropping system model.Euro. J. Agron., 18:235-265.

Mall, R.K., Sonkar, G., Bhatt, D., Sharma, N.K., Baxla,A.K. and Singh,K.K. (2016).Managing impact of extreme weather events in sugarcane in different agro-climatic zones of Uttar Pradesh.Mausam, 67:233-250.

Mishra, S.K., Shekh, A.M., Pandey, V., Yadav, S.B. and Patel, H.R. (2015). Sensitivity analysis of four wheat cultivars to varying photoperiod and temperature at different phenological stages using WOFOST model. $J$. Agrometerol., 17(1):74-79.
Mishra, S.K., Singh, G. and Singh, K. (2017). Sugarcane growth and yield simulation under varying planting dates in sub-tropical India. J. Agrometerol., 19 (special issueAGMET 2016):200-204.

Singels, A. and Bezuidenhout, C.N. (2002). A new method of simulating dry matter partitioning in the CANEGRO sugarcane model.Field Crops Res., 78:151-164.

Singh, K.K., Mall, R.K., Singh, R.S. and Srivastava, A.K. (2010).Evaluation of CANEGRO Sugarcane model in East Uttar Pradesh. J.Agrometeorol., 12(2):181-186. 